\title{
Refractory B-Cell Non-Hodgkin Lymphoma
}

National Cancer Institute

\section{Source}

National Cancer Institute. Refractory B-Cell Non-Hodgkin Lymphoma. NCI Thesaurus. Code C8842.

B-cell non-Hodgkin lymphoma that is resistant to treatment. 